\title{
Bats as bushmeat in Madagascar
}

Richard K. B. Jenkins ${ }^{\prime, \|}$ and Paul A. Racey"

\section{ABSTRACT}

Bats are eaten by people throughout Madagascar and although the larger species like Pteropus rufus, Eidolon dupreanum, Rousettus madagascariensis and Hipposideros commersoni are preferred, small insectivorous bats are also eaten. The national hunting season for bats is widely ignored and both unsuitable hunting practices and high offtake represent a serious threat to bat populations in some areas. Bat bushmeat may be an important source of protein for Malagasy people during periods of food shortage but in general there are few data on the socioeconomic and cultural importance of bats. Fruit bats produce a single offspring per year and are therefore susceptible to over-hunting. Nevertheless, large roosts offer the possibility of community managed harvests to secure the colony and provide a source of meat but further research is needed before this can be considered. Roost sites also present the best focus for conservation and greater effort is needed to control hunting using existing legislation and flexible community-based solutions that are sensitive to the local context. The threat of pathogen transfer from bats to people is of growing concern as more bat species are identified as vectors of emergent viral diseases.

\section{RÉSUMÉ}

Les gens consomment des chauves-souris partoutà Madagascar et s'ils préfèrent les plus grandes espèces comme Pteropus rufus, Eidolon dupreanum, Rousettus madagascariensis et Hipposideros commersoni, les petites chauves-souris insectivores sont également consommées. La période d'ouverture nationale de la chasse n'est généralement pas respectée et I'on assiste aussi bien à de mauvaises pratiques cynégétiques qu'à des prélèvements importants qui représentent une menace sérieuse pour les populations de chauves-souris dans certaines régions. Les chauves-souris peuvent constituer une source de protéines importante pour les populations villageoises pendant les périodes de soudure alimentaire mais en règle générale, il existe peu de données sur les valeurs socio-économiques ou culturelles des chauves-souris. Les chauves-souris frugivores ne produisent qu'un seul jeune par an, de sorte qu'elles sont sensibles à la pression de chasse bien que les grands dortoirs pourraient offrir l'occasion d'une

\author{
Correspondence: \\ Richard K. B. Jenkins \\ Madagasikara Voakajy, B. P. 5181 \\ Antananarivo (101), Madagascar \\ E-mail: jenkins@moov.mg,r.jenkins@abdn.ac.uk
}

exploitation gérée par la communauté pour assurer la sécurité des colonies et fournir une source de protéines mais de plus amples recherches sont nécessaires avant que cette alternative ne puisse être retenue. Les dortoirs constituent également les meilleures cibles des actions de protection de la nature et des efforts plus importants sont nécessaires pour contrôler la chasse en s'appuyant sur la législation nationale ainsi que sur des solutions locales plus souples et adaptées, basées sur la communauté. Les chauves-souris peuvent aussi transmettre des agents pathogènes et cette menace est une source d'inquiétude grandissante car de plus en plus d'espèces de chauves-souris ont été identifiées en tant que vecteurs de maladies virales émergentes.

KEYWORDS: bats, bushmeat, Eidolon, Hipposideros, hunting, Pteropus, Rousettus, roost

\section{INTRODUCTION}

Hunting of wildlife for food is a major threat to forest vertebrates in the tropics (Wilkie et al. 1998. Bakarr et al. 2001, Fa et al. 2002, Corlett 2007), but wild meat provides people with a vital source of protein and income (de Merode et al. 2004). Understanding the dynamics of bushmeat hunting, consumption and trade, especially the supply and demand of species that are of conservation concern, is a priority in areas where exploitation levels are high. For the more productive and abundant species, sustainable extraction may be possible, thus enabling local communities to use this resource for food and income (Robinson and Bennett 2004).

Most bushmeat studies in Africa have concentrated on central and western tropical forests on the mainland (e.g. Bakarr et al. 2001, Fa et al. 2005, Willcox and Namu 2007). By contrast, there are only a few accounts from the island of Madagascar, but there is evidence of an established hunting culture that points to regular consumption of terrestrial and flying vertebrates for food (Linton 1933). Wild animals that are hunted and consumed by people in Madagascar include lemurs, tenrecs, carnivores, bats, birds and reptiles (Randriamanalina et al. 2000, Garcia and Goodman 2003, Goodman and Raselimanana 2003, Goodman et al. 2004, Rakotondravony 2006). 


\section{VOLUME 3 ISSUE 1

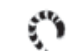 DECEMBER 2008 MADAGASCAR \%, CONSERVATION \& DEVELOPMENT}

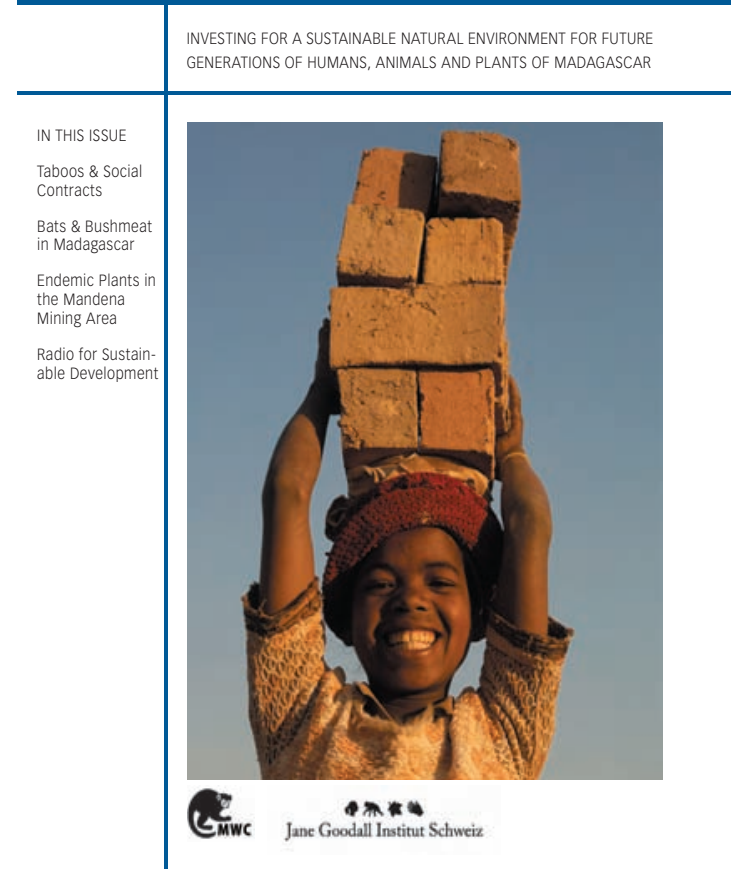

Madagascar Conservation \& Development is the journal of Madagascar Wildlife Conservation (MWC) and the Jane Goodall Institute (JGI Switzerland). It is produced in these institutions' own responsibility.

All the Issues and articles are freely available at http://www.mwc-info.net/en/services/journal.htm

Contact Journal MCD

info@journalmcd.net for general inquiries MCD funding@journalmcd.net for supporting the journal

Journal Madagascar Conservation \& Development Institute and Museum of Anthropology University of Zurich

Winterthurerstrasse 190

$\mathrm{CH}-8057$ Zurich, Switzerland

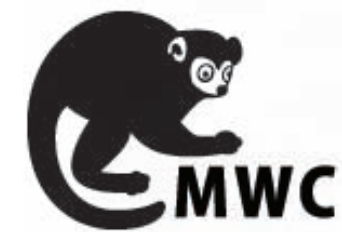

contact@mwc-info.net for general inquiries

Postfach 2701

CH-8021 Zürich, Switzerland

Logement 11, Cité Andohaniato Antananarivo 101, Madagascar

info@janegoodall.ch for general inquiries JGI

\section{$2 \pi$}

Jane Goodall Institut Schweiz
Switzerland

Postfach 2807

8033 Zürich, Switzerland 
There are accounts of lemur hunting from Daraina in the north (Rakotondravony 2006), Parc National (PN) de Kirindy-Mite in the southwest, (Goodman and Raselimanana 2003), PN d'Ankarafantsika in the west (Garcia and Goodman 2003), Makira in the northeast (Golden 2005) and Fort Dauphin in the southeast (Randriamanalina et al. 2000). Lemurs are protected by Malagasy law but many species are hunted using baited traps, blowpipes, shot guns, catapults, dogs or spears.

Other frequently hunted mammals include tenrecs (Tenrecidae, Afrosoricida) and Bush pigs Potamochoerus larvatus (Goodman and Raselimanana 2003, Golden 2005, Rakotondravony 2006), and there is evidence that carnivores are also hunted and consumed in some areas, e.g. Makira (Golden 2005) and PN d'Ankarafantsika (Garcia and Goodman 2003). Reptiles are also eaten and although snakes are reportedly consumed (Rakotondravony 2006), the greatest demand is for tortoises and sea turtles (Garcia and Goodman 2003, Goodman and Raselimanana 2003, O'Brien et al. 2003, Goodman et al. 2004). Birds are also important bushmeat across the country (Garcia and Goodman 2003, Goodman et al. 2004, Rakotondravony 2006).

This review focuses on the hunting and human consumption of bats by people in Madagascar. As interest in the bats of Madagascar has increased in recent years significant advances have been made in understanding taxonomy, foraging and diet, and habitat use (Goodman and Ranivo 2004, Goodman et al. 2005, Andriafidison et al. 2006, Andrianaivoarivelo et al. 2006, Bates et al. 2006, Jenkins et al. 2007a, Picot et al. 2007). There are relatively few accounts of bats as bushmeat in Madagascar although the limited information available suggests that hunting levels of megachiropterans (Mackinnon et al. 2003), and at least one microchiropteran species (Goodman 2006), are high. The extent and frequency of bat hunting varies seasonally and geographically (Mackinnon et al. 2003) and not all hunting surveys have found evidence of bats as bushmeat (e.g. PN d'Ankarafantsika, Garcia and Goodman 2003; Mikea Forest, Goodman et al. 2004).

Madagascar now has close to 40 species of bats, $70 \%$ of which are endemic (Racey et al. in press). They constitute a significant proportion of the island's mammalian diversity and play an important role as long-distance seed dispersers and pollinators (Bollen and van Elsacker 2002, Andriafidison et al. 2006, Picot et al. 2007). The three species of endemic Megachiroptera that occur on Madagascar were all considered to be threatened by hunting in the 2005 IUCN Global Mammal Assessment workshop in Antananarivo; Pteropus rufus and Eidolon dupreanum were classified as Vulnerable and Rousettus madagascariensis as Near-Threatened. There was little available information on the hunting of microchiropterans but the endemic insectivorous Hipposideros commersoni was also classified as Near-Threatened because of the reported impact of hunting.

In this review we collate data on bats as bushmeat, both published and unpublished, and report on general trends with respect to hunting methods, consumption patterns, conservation threats and human livelihood issues. We draw on personal experience in the field since 1998 (PAR) and 2002 (RKBJ) and have augmented the accounts by personal reports from our Malagasy colleagues engaged as either employees or students in successive projects organized by the University of Aberdeen and funded by the Darwin Initiative (1999-2005). Information on bat hunting was obtained through direct observations as well as informal discussions with people in a range of sites across the island (Figure 1).

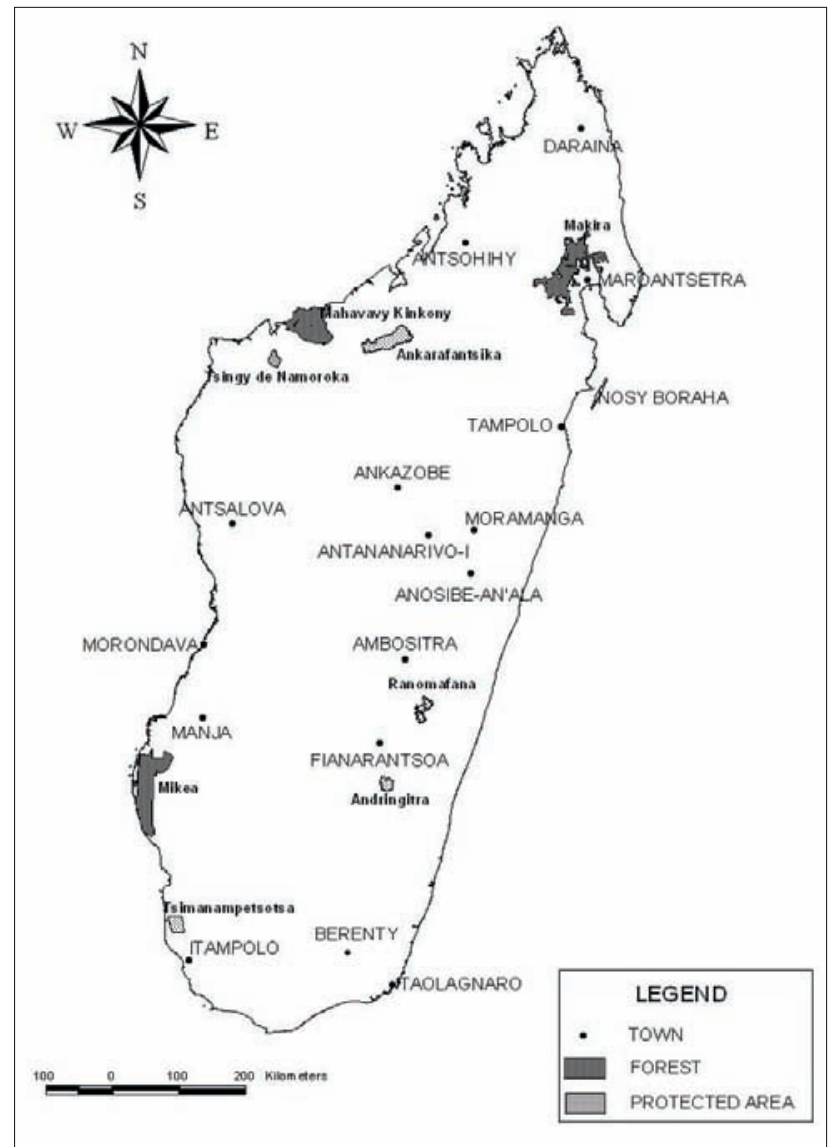

FIGURE 1. Map of Madagascar showing the location of protected areas and towns names mentioned in the text and Table 1.

HUNTING BATS FOR MEAT The life history of bats is divided between the sites used for resting during the day ('roost') and the areas used at night for feeding. These two areas are often spatially distinct and can, for Pteropus rufus, be over $40 \mathrm{~km}$ apart (Racey et al. in press). People in Madagascar usually hunt bats either at roosting sites, where they aggregate, or at feeding sites where they forage in close proximity to human habitation (Table 1).

Fruit bats are very vulnerable to capture at night when they feed on fruits and flowers at low heights and close to villages. This type of exploitation is mainly for subsistence purposes and occurs in many areas of Madagascar. In the Menabe Region of western Madagascar local people use nets or natural hooks from plants such as Uncarina grandidieri (Pedaliaceae) to catch and snare foraging bats respectively (Figure 2). In southern Madagascar Pteropus rufus is netted when it feeds on sisal (Agave sisalana, Agavaceae) plants at night and at least some of the bats are sold locally (Rahaingodrahety 2007). Sometimes the need for obtaining bushmeat is secondary to protecting important fruit crops from the bats, as was reported by Andrianaivoarivelo et al. (2007) from Anosibe An'ala in the Alaotra Mangoro Region. Farmers in the Anosy Region also reported consumption of the bats killed during crop protection efforts (Rahaingodrahety 2007). Microchiropterans are hunted in small numbers away from their roost during foraging flights, especially when they are attracted to insect swarms around artificial lights or exceptionally when commuting bats are funneled into narrow spaces (Table 1). 
TABLE 1. Summary of the species, methods and locations relating to bats as bushmeat in Madagascar. Personal communications refer to the following individuals (1: D. Andriafidison, 2: M. M. Picot, 3: H. J. Razafimanahaka, 4: A. Rabearivelo 5: F. H. Randrianandrianina, 6: C. Rahaingonirina, 7: A. R. Andrianaivoarivelo).

\begin{tabular}{|c|c|c|c|c|c|c|}
\hline Type & Site & Bat Species & Period & Location & Methods & Source \\
\hline Roosting & Cave & Emballonura atrata & Not known & Near Brickaville & Collection in sacks & Pers. Comm. (1) \\
\hline Roosting & Rock crevice & Eidolon dupreanum & All year & East (Anosibe An'ala) & Ladder & Pers. Comm. (6) \\
\hline Roosting & Rock crevice & E. dupreanum & All year & Widespread & Fire and sticks & Ranivo (2001) \\
\hline Roosting & Rock crevice & E. dupreanum & All year & Highlands & Rope descent & $\begin{array}{l}\text { P. A. Racey } \\
\text { (Unpubl. data) }\end{array}$ \\
\hline Roosting & Rock crevice & E. dupreanum & Oct.- Jul. & Highlands & Nets & Ranivo (2001) \\
\hline Roosting & Rock crevice & E. dupreanum & Oct.-Jul. & Highlands & Collection in a sack & Ranivo (2001) \\
\hline Feeding & $\begin{array}{l}\text { Eucalyptus } \\
\text { spp. flowers }\end{array}$ & E. dupreanum & Mar.-Apr. & $\begin{array}{l}\text { Centre } \\
\text { (near Fianarantsoa) }\end{array}$ & Nets & Pers. Comm. (2) \\
\hline Feeding & $\begin{array}{l}\text { Ceiba pentandra } \\
\text { flowers }\end{array}$ & E. dupreanum & May-Jul. & $\begin{array}{l}\text { West } \\
\text { (Manja to Antsohihy) }\end{array}$ & $\begin{array}{l}\text { Guns, nets, plant parts } \\
\text { slingshots }\end{array}$ & Pers. Comm. (1) \\
\hline Feeding & Feeding perch & Hipposideros commersoni & Jan.-Mar. & East (Tampolo) & Sticks & Pers. Comm. (3) \\
\hline Roosting & Caves & H. commersoni & Jan.-Mar. & South (Itampolo) & Sticks & Goodman (2006) \\
\hline Roosting & Foliage & H. commersoni & Feb.-May & West (Ankarafantsika) & Knocked from roost & Pers. Comm. (3) \\
\hline Feeding & Ripe Litchi chinensis & Megachiroptera & Dec. & East (Anosibe An'ala) & Nets & $\begin{array}{l}\text { Andrianaivoarivelo } \\
\text { et al. } 2007\end{array}$ \\
\hline Feeding & Ripe Eugenia jambos & Megachiroptera & Jan.-Mar. & $\begin{array}{l}\text { East (Andilamena / } \\
\text { Lac Alaotra) }\end{array}$ & Nets & Pers. Comm. (4) \\
\hline Feeding & Commuting route & Microchiroptera & All year & West (Antsalova) & Sticks & $\begin{array}{l}\text { R. K. B. Jenkins } \\
\text { (Unpubl. data) }\end{array}$ \\
\hline Roosting & Caves & Miniopterus gleni & Jan.-Mar. & South (Itampolo) & Sticks & Goodman (2006) \\
\hline Roosting & Caves & Miniopterus manavi & Not known & East (Makira) & & Golden (2005) \\
\hline Roosting & Foliage (Ravenala) & Myzopoda aurita & All year & East (Tampolo) & Picked from inside plants & Pers. Comm. (3) \\
\hline Feeding & $\begin{array}{l}\text { Ceiba pentandra } \\
\text { flowers }\end{array}$ & Pteropus rufus & May-Jul. & $\begin{array}{l}\text { West } \\
\text { (Manja to Antsohiy) }\end{array}$ & $\begin{array}{l}\text { Guns, nets, plant parts, } \\
\text { slingshots }\end{array}$ & Pers. Comm. (1) \\
\hline Feeding & Sisal flowers & P. rufus & All year & $\begin{array}{l}\text { Near Berenty } \\
\text { Private Reserve }\end{array}$ & Nets & $\begin{array}{l}\text { Rahaingodrahety } \\
2007\end{array}$ \\
\hline Feeding & Ficus spp. fruit & P. rufus & All year & Widespread & Nets & Pers. Comm. (1) \\
\hline Roosting & Emergence sites & P. rufus & All year & Widespread & Nets & Pers. Comm. (2) \\
\hline Roosting & Roosting perch & P. rufus & All year & East (Moramanga) & Roost trees felled & Jenkins et al. 2007a \\
\hline Roosting & Roosting perch & P. rufus & All year & Widespread & Guns & Pers. Comm. (1) \\
\hline Roosting & Caves & P. rufus & Not known & East (Makira) & Not known & Golden (2005) \\
\hline Roosting & Caves & Rousettusmadagascariensis & All year & East (Nosy Boraha,) & Sticks & $\begin{array}{l}\text { Rakotondrasana and } \\
\text { Goodman } 2007\end{array}$ \\
\hline Feeding & Litchi trees & R. madagascariensis & Dec., Jan. & East (Anosibe An'ala) & Shotgun & Pers. Comm. (7) \\
\hline Roosting & Caves & R. madagascariensis & All year & East (Anosibe An'ala) & Sticks & Pers. Comm. (6) \\
\hline Roosting & Caves & R. madagascariensis & Oct.- Mar. & East (Tolagnaro) & Trap & Jenkins et al. 2007b \\
\hline Roosting & Caves & R. madagascariensis & Not known & East (Makira) & Not known & Golden (2005) \\
\hline Roosting & Caves & Triaenops rufus & Jan.-Mar. & South (Itampolo) & Sticks & Goodman (2006) \\
\hline
\end{tabular}

Many Malagasy bat species roost in some form of cavity, such as caves, fissures, roofs or tree holes (Racey et al. in press) and hunting occurs both inside the roosts and as the bats emerge or return (Table 1)

Rousettus madagascariensis is a small fruit bat (50-60g) that roosts in caves and although it is widespread, relatively few roosts have been discovered by biologists thus far (Mackinnon et al. 2003). Even though some roosts are protected from hunters because they occur in protected areas (Kofoky et al. 2007) or sacred sites (Rakotoarivelo and Randrianandrianina 2007), there are many reports of hunting in and around caves (Rakotondrasana and Goodman 2007, Jenkins et al. 2007b). A common method is to throw sticks at the roosting bats and collect the animals that fall, or strike them as they emerge from the cave (Rakotondrasana and Goodman 2007) before taking the animals back to the village (Figures 3 and 4). Goodman (2006) described the hunting method for Hipposideros commersoni, Miniopterus gleni and Triaenops rufus by villagers near Itampolo. Narrow 


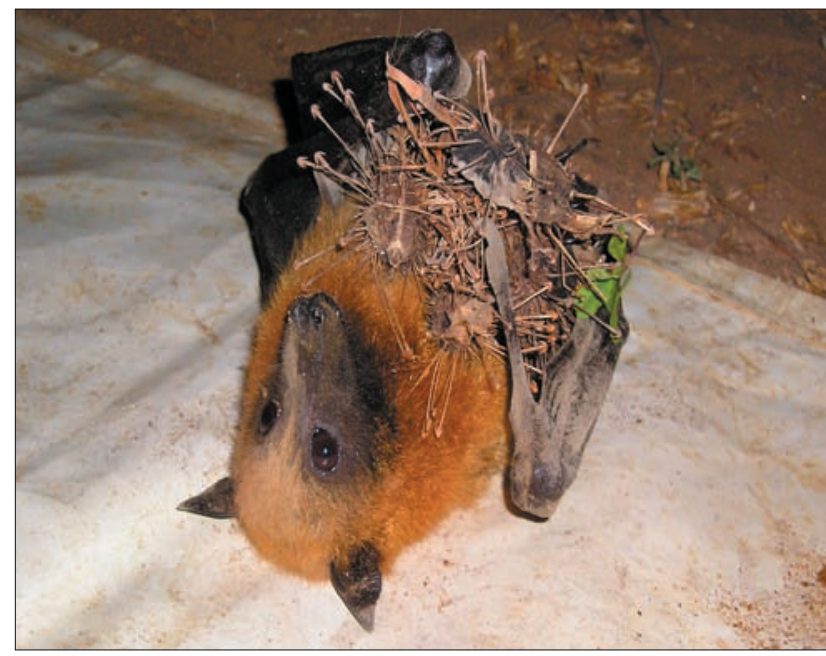

FIGURE 2. Pteropus rufus snared using hook-like plant burrs whilst feeding on kapok trees near Kirindy-Mite National Park (Photo: R. A Andrianaivoarivelo)

flyways were cleared in the vegetation surrounding the cave entrance and the bats were swatted with a wooden whip-like baton as they emerged (Figure 5).

Eidolon dupreanum and some molossids roost in fissures E. dupreanum is a medium-sized megachiropteran (300 g) that is hunted for meat in many parts of Madagascar (Ranivo 2001, MacKinnon et al. 2003). Its roost sites are usually very high and located in cliffs and rock faces, making direct access by hunters difficult. Hunting is usually undertaken by specialists who either access roosts with wooden ladders or light fires directly underneath the roosts and net or swat flying bats as they emerge (Table 1). Alternatively, a hunter is lowered on a rope and hits the bats with a stick as they emerge (Table 1).

Only a few Malagasy bat species roost in foliage, notably Pteropus rufus, Myzopoda aurita and Hipposideros commersoni. The latter species roosts singly in trees at some sites but is difficult to locate during the day and we know of only one area where the bats are taken from trees and eaten. In PN d'Ankarafantsika local people collect a forest tuber (Dioscorea maciba, Dioscoreaceae) and occasionally encounter roosting $H$. commersoni which are taken back to the village and eaten (Table 1). In the area around Tampolo forest, people collecting leaves of the Travellers' palm (Ravenala madagascariensis Strelitziaceae) for housing materials often encounter $M$. aurita roosting in the unfurled leaves. Although there was no evidence that bats were deliberately sought, they were collected and taken back to the village where they were cooked and eaten. The Madagascar flying fox P. rufus is the island's largest bat (ca. 600 g) and roosts in the upper branches of large trees. It forms large (up to 5,000 individuals, Mackinnon et al. 2003), noisy colonies and is the main source of bat bushmeat in Madagascar. In many regions nets are erected inside or on the periphery (Figure 6) of roosts to intercept flying bats (Jenkins et al. 2007b). Firearms, notably shotguns, are also used to hunt $P$. rufus is many areas. In eastern Madagascar individual trees with roosting bats are felled by hunters who club the fallen animals with sticks (Mackinnon et al. 2003).

BATS AS BUSHMEAT There are few eye-witness accounts

from biologists on the seasonality and frequency of hunting or the destination of the bat meat, and most reports are based

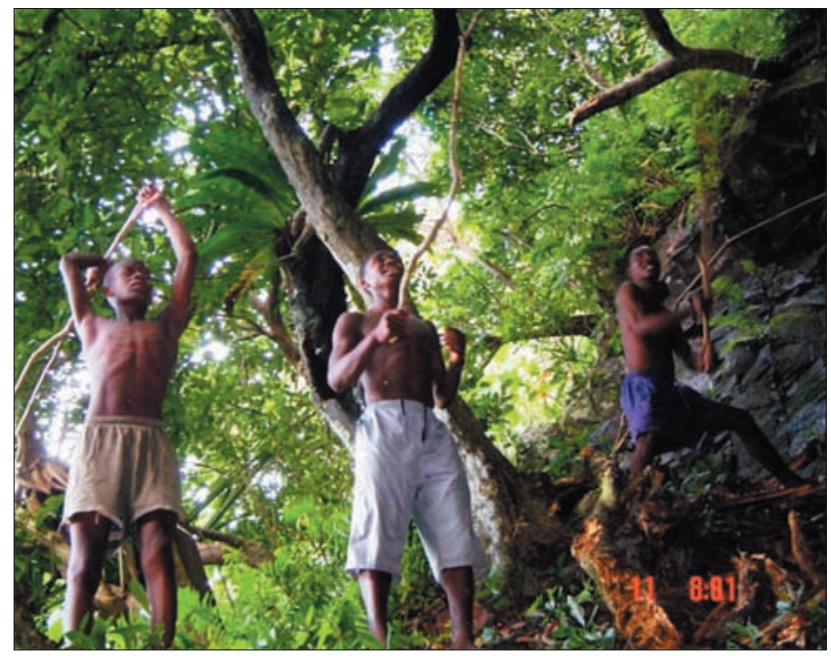

FIGURE 3. Hunting Rousettus madagascariensis on Nosy Boraha: one man in the cave disturbs the bats by throwing sticks and his fellow hunters wait at the cave entrance to strike emerging bats (Photo: F. H. Randrianandrianina).

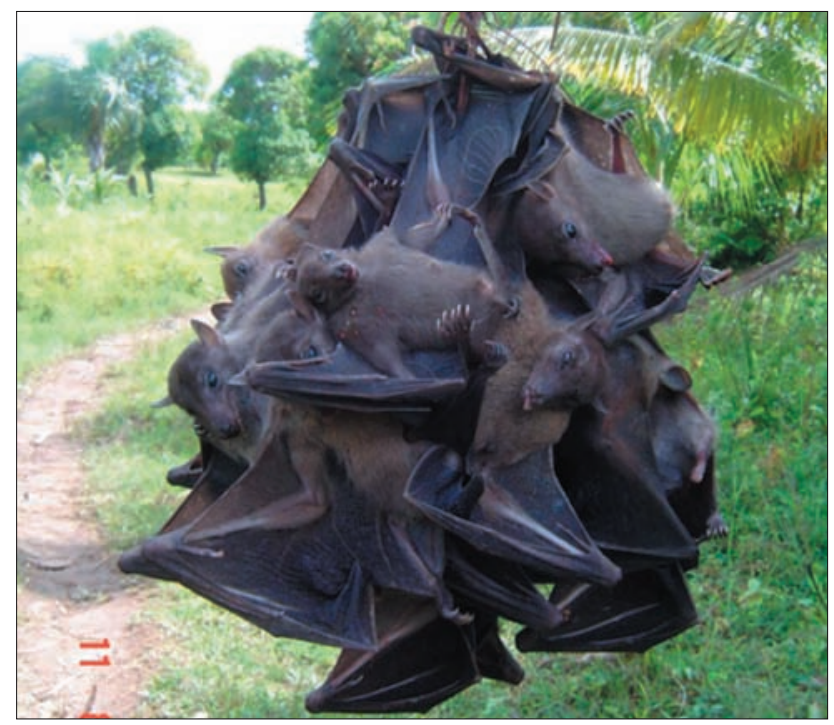

FIGURE 4. The results of a daily hunting trip to a cave roost of Rousettus madagascariensis on Nosy Boraha (Photo: F. H. Randrianandrianina).

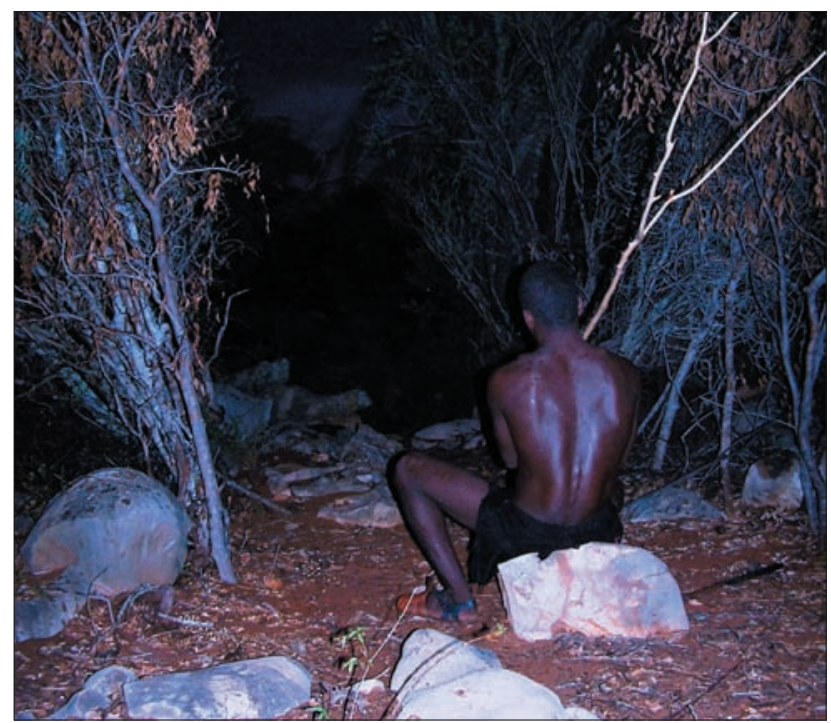

FIGURE 5. A hunter near Itampolo poised at the 'mouth' of a ride cut in the forest from the cave to channel the emerging Hipposideros commersoni towards his long stick (Photo: H. J. Razafimanahaka). 


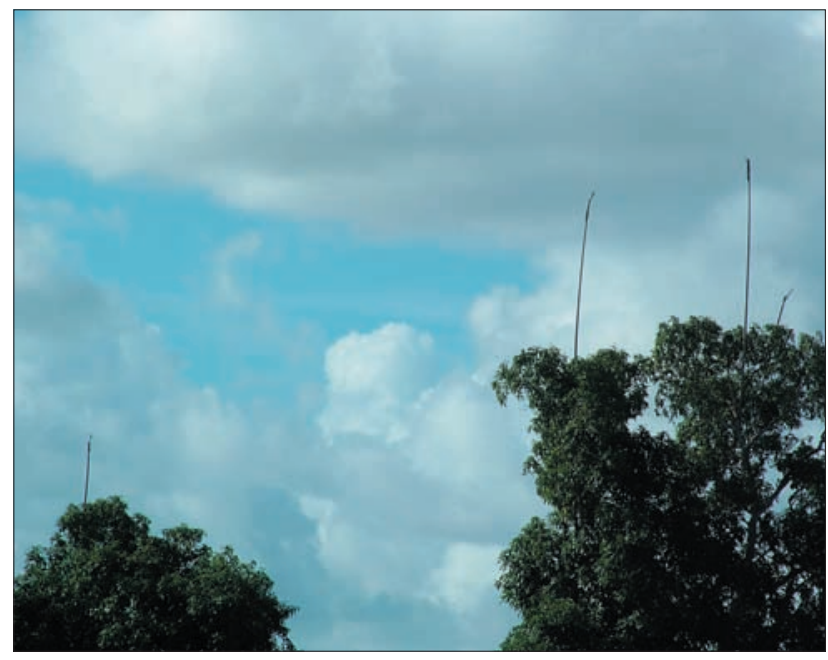

FIGURE 6. Support poles for nets set permanently around the edge of a Pteropus rufus roost in western Madagascar (Photo: R. Randrianavelona).

on informal interviews (Rakotoarivelo and Randrianandrianina 2007, Rakotonandrasana and Goodman 2007) or brief observations (Goodman 2006). Quantitative information in particular is lacking and this prohibits a thorough assessment of sustain ability. Nevertheless, it is possible to obtain an overview of the way in which bat bushmeat is traded and used in Madagascar.

Pteropus rufus is hunted in the Daraina area in northeastern Madagascar (Rakotondravony 2006) where roosts of over 1,000 animals have been reported from littoral forest. Although the people living around the roost refrain from eating the bats, the colonies are reportedly subject to frequent hunting by local immigrants (Rakotondravony 2006). In Makira, P. rufus is eaten widely by local communities and at $\$ 1.5$ US / $\mathrm{kg}$ was the most expensive bushmeat and also exceeded the price of meat from most domesticated animals (Golden 2005). During July 2007 near Morondava, the price of $P$. rufus in restaurants exceeded beef, chicken and duck dishes, was the same as eel, and only tenrecs fetched a higher price (Figure 7). In the Mahavavy-Kinkony area of western Madagascar, regular hunting at a P. rufus roost was reported by Rakotoarivelo and Randrianandrianina (2007); hunting teams of up to eight men visited the roost on a regular basis and caught up to 100 bats on each occasion. These were sold around villages and to local restaurants for \$0.5 US each. On Nosy Boraha, $P$. rufus is regularly exploited from at least one roost and is served seasonally in restaurants in the main town on the island (Rakotonandrasana and Goodman 2007). One hunter also reported that frozen shipments of $P$. rufus are sent to the mainland port of Toamasina (Rakotonandrasana and Goodman 2007). At a small restaurant near Mahajanga in 2000, at least 30 P. rufus were reportedly sold every day (Figure 8 ), although it is not clear whether this figure is a monthly average estimate or reflects a seasonal peak in availability (Racey et al. in press). In the sisal plantations surrounding Berenty Private Reserve, hunters can expect to catch 8-12 P. rufus per week between September and May and 25-30 between June and August. Bats are sold discretely in villages around the reserve for \$0.7-1.0 US. Extrapolating these figures, a single hunter could catch between 164 and 192 bats per year (Rahaingodrahety 2007).

During a study on the diet of Eidolon dupreanum in the rainforest between PN de Ranomafana and PN d'Andringitra, a number of accounts on bat hunting were collected from villages (Picot 2005). Although familiar with the location of the bat roosts, the local people rarely hunted or consumed the bats. Professional hunters visited a few times a year and occasionally offered bat meat to the village but most of the animals were taken to larger towns and sold for $\$ 0.4$ US each to restaurants and hotels. In this area the oil residue from cooked bats is used as medicine for whooping cough. Further north in the highlands, Ranivo (2001) investigated the hunting of E. dupreanum at roost sites near Ambositra, Antsirabe and Ankazobe. Villagers reported purchasing E. dupreanum directly from hunters between one and four times per year (Ranivo 2001).

The large fruit bats, Pteropus rufus and Eidolon dupreanum, appear to be the only species sold in restaurants. They are either served individually, complete with head and wings, jointed, or are diced up into small pieces and accompanied by rice (Figure 9). Small bats that are prepared in rural settings are often cooked together in large metal saucepans, whilst Hipposideros commersoni is either roasted over a fire or boiled (Figure 10). There is little evidence that people have distinct preferences for particular bat species and although larger species are usually the most sought after (explaining the prevalence of fruit bats and $H$. commersoni as bushmeat), there are accounts of people hunting the small (ca. $6 \mathrm{~g}$ ) sheath-tailed Emballonura from caves in eastern Madagascar (Table 1).

THE IMPACT OF BAT HUNTING Rakotondravony (2006) considered hunting to represent a minor threat to $P$. rufus in the north of Madagascar, but noted that this species was frequently served in local restaurants. Other evidence suggests that, at last locally, current patterns of exploitation are unsustainable and this is obviously of concern to conservationists and those who depend on the bats for income and nutrition. Local

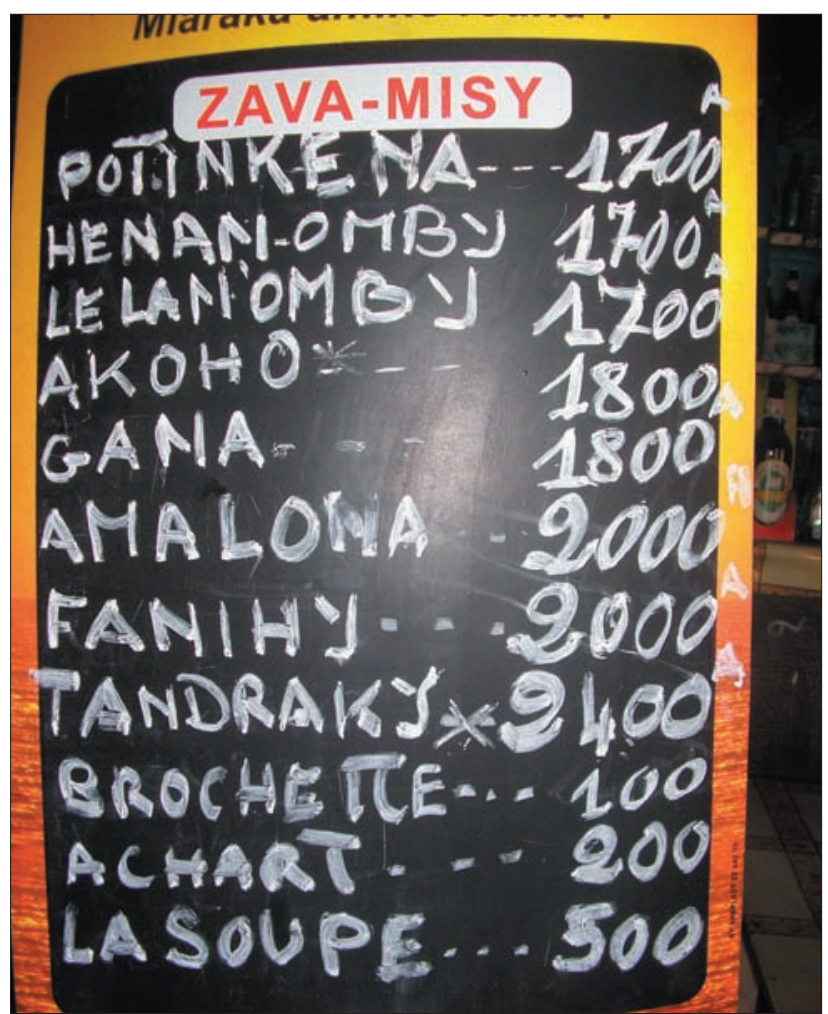

FIGURE 7. A menu in a roadside restaurant in western Madagascar during July 2007 showing the price of fruit bat fanihy as 2,000 ariary or \$1 US. Other meats on the menu are omby (beef), akoho (chicken), gana (duck), amalona (eel) and tandraky (tenrec). (Photo: F. H. Randrianandrianina), 

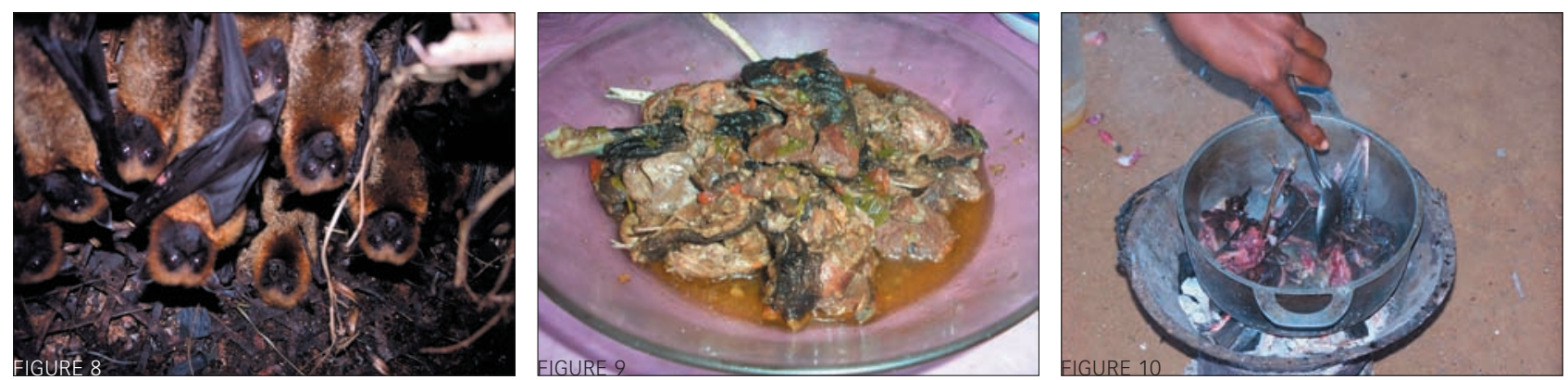

FIGURE 8. Pteropus rufus in a cage in the kitchen of a small roadside restaurant in western Madagascar (Photo: J. L. Mackinnon).

FIGURE 9. Fruit bat served in a home in western Madagascar (Photo: F. H. Randrianandrianina).

FIGURE 10. Hipposideros commersoni being cooked in a small village in western Madagascar (Photo: H. J. Razafimanahaka).

extirpation would also result in a loss of the important ecological services provided by fruit bats.

Ranivo (2001) found that hunting Eidolon dupreanum caused the bats to abandon traditional roost sites and local people noted declines in hunting returns. Golden (2005) reported that the large annual harvests of Rousettus madagascariensis and Pteropus rufus in the Makira forest and Maroantsetra were unsustainable and Goodman (2006) concluded that harvest level of Hipposideros commersoni (ca. 70,000-140,000 bats annually) surpasses the likely productivity of the species in the area. Furthermore, simple extrapolation of the reported 30 bats per day served in a restaurant in the west (Racey et al. in press) results in over 10,000 bats served per year, a number that suggests a large catchment area and the presence of dedicated hunting teams. Hunting for $\mathrm{H}$. commersoni at the Mitoho Cave in PN de Tsimanampetsotsa may have been the reason for this species to abandon the site (Goodman et al. 2002). Furthermore, high desertion rates of E. dupreanum and P. rufus in the central highlands was attributed to over-hunting (Mackinnon et al. 2003). There is therefore growing evidence that hunting is threatening the existence of fruit bat roosts across Madagascar although it should be noted that there are probably examples of low level subsistence hunting that continues at a sustainable level.

BAT BUSHMEAT AND HUMAN LIVELIHOODS There

are few accounts of the relationship between bat bushmeat and human livelihoods in Madagascar. In general, bats appear to contribute either to the livelihoods of hunters who collect bats to order, to sustain the demand from restaurants, or are important as a subsistence food that provides protein for the hunter and local village. Goodman (2006) reported that the harvest of Hipposideros commersoni in the south occurred when the bats had accumulated fat deposits and people were experiencing food shortages. If this scenario is representative of other areas of Madagascar then the bat meat may be a crucial dietary component for people living with low food security.

There is growing evidence that bats harbor diseases that may infect humans (Messenger et al. 2003, Breed et al. 2006). In a preliminary study on Malagasy fruit bats antibodies to Henipa and Tioman virus were found in a small number of samples suggesting that these viruses have been present (lehlé et al. 2006). In addition to eating bats, humans also eat fruit that has been in contact with bats and in some areas large roosts of microchiropterans occupy the roof spaces of schools and hospitals. More information is now needed on the risk of pathogen transmission to humans from eating bat meat or through direct contact with bat feces and urine because any assessment of the positive livelihood contribution from bats needs to consider the potential impact to human health.

\section{DISCUSSION}

Bats are hunted and consumed by people throughout Madagascar but the economic importance of the meat, the hunting industry, and its impact on the survival of bat populations remain poorly understood. Whilst it is possible that some traditional methods of harvesting bats are sustainable there are increasing reports of the collection of large, and presumably unsustainable, numbers of bats. In other islands traditional, low-level and presumably sustainable, flying fox harvests have been replaced by chronic over-hunting associated with the proliferation of firearms (Brooke and Tschapka 2002, Monson et al. 2003). Firearms are used in Madagascar and elsewhere to hunt bats but shotguns and ammunition are relatively expensive and are not yet widely used; most hunting is still carried out using nets, sticks and traps.

The value of bat bushmeat to individuals and communities has yet to be established in Madagascar but mammals in mainland Africa provide a vital source of protein and income for rural communities, with the importance of bushmeat to households varying according to family wealth and season (de Merode et al. 2004). Bushmeat hunting is also thought to lead to a decrease in population size and a concomitant decline in ecosystem function through the loss of seed dispersers, grazers and browsers (Corlett 2007). Malagasy fruit bats play an important role in seed dispersal and pollination and the maintenance of these services requires healthy bat populations. There are therefore compelling reasons to conserve bats in Madagascar but also to allow some level of hunting because of the traditional and socioeconomic value of the meat. Balancing these factors is a major challenge for conservationists.

In mainland Africa, forest antelopes and primates contribute most biomass to bushmeat (de Merode et al. 2004) and bats are much less frequently encountered (e.g. Wilcox and Nambu 2007). Fa et al. (2006) found that bats (Eidolon helvum) had one of the lowest extraction levels of over 50 forest mammals in Nigeria and Cameroon. However, colonies of roosting bats are not necessarily associated with tropical forests (Halstead 1977, Mickleburgh et al. 1992) and there is evidence of bat hunting from more urban settings (Funmilayo 1976, 1978). Comparisons with tropical Asia are also relevant given the distribution of pteropodid bats. Lee et al. (2005) found that large pteropodid 
bats were one of the most commonly traded wild meats on north Sulawesi and the demand was high enough to result in the probable extirpation of colonies. On Indonesian Borneo, Pteropus vampyrus natunae is hunted at feeding sites to supply the provincial demand for bat meat (Struebig et al. 2007). Pteropus bats occur on many of the small islands in the Indo-Pacific Region and continue to be an important traditional source of food but over-hunting is thought to be the cause of population declines in many species (Heaney and Heideman 1987, Mickleburgh et al. 1992, Craig et al. 1994, Bowen-Jones et al. 1997, Wiles et al. 1997, Brooke and Tschapka 2002)

Malagasy bats are classed as game under Malagasy law and there are two defined hunting seasons, one for fruit bats and the other for Hipposideros commersoni (Durbin 2007). However, the seasonality of bat hunting appears to depend mostly on the availability of the bats rather than the legal hunting season. The ephemeral nature of fruit and flowers means that hunters can only trap foraging bats at certain times of the year, which can, as in the case of kapok (Ceiba pentandra Malvaceae), coincide with the hunting season. The period when litchis (Litchi chinensis Sapindaceae) are ripe (November to January) affords the opportunity for hunters to trap fruit bats outside of the open season (1 May-1 September for all fruit bats). H. commersoni in the south is hunted between December and March, a period that partially coincides with the hunting season for this species (1 February-1 May). It is therefore important to establish that, even though bat hunting is reported to cause roost desertions and is locally unsustainable (Golden 2005, Goodman 2006, Racey et al. in press) there is only a very weak legal framework which conservationists can use to control bat hunting. In some areas hunters are reported to release pregnant females or to refrain from hunting during the period of pregnancy. This type of management is based on local knowledge of bat biology and does not correspond to the legal hunting season because most bat species in Madagascar are pregnant between August and December. The bat roosts that are located in Madagascar's network of parks and nature reserves receive full protection from hunting and the creation of new protected areas offers the opportunity to conserve important roosts. However, some species like Pteropus rufus appear rather rare in the existing system of protected areas (MacKinnon et al. 2003) and because illegal hunting in parks is known to occur (Garcia and Goodman 2003, Cardiff 2006), management teams should regularly monitor important bat roosts to deter hunting.

Culture and tradition play an important role in determining patterns of bushmeat exploitation. Taste preferences vary according to region and ethnic group and account for some of the variation in the consumption of bat meat across Madagascar (Mackinnon et al. 2003). Some bat roosts receive total protection from hunters because they are located in sacred burial sites (Rahaingodrahety 2007, Rakotoarivelo and Randrianandrianina 2007).

The large size of Madagascar and the geographical distribution of bat roosts prohibit a well organized annual hunt of the type reported from small oceanic islands (Brooke and Tschapka 2002). Managed harvests may work best if the local traditions are taken into account which in Madagascar would require regional flexibility in the timing and duration of hunting periods. Given the variability of fruiting seasons for many plant taxa, studies should be carried out in several regions before these measures can be considered. Any recommendations on how to reconcile hunting and bat conservation need also to be based on regional assessments of the bushmeat trade, and such data are currently lacking. Long-term information on population change and roost occupancy is also needed because any impact of hunting may be exacerbated by the loss of roosts to agricultural expansion.

Conservationists recognize the importance of bushmeat to rural livelihoods and this is manifest in the quest for sustainable harvests to maintain wildlife populations and support human populations. There are a number of publications about sustainably harvesting terrestrial mammals (Fitzgibbon et al. 1995, Wilkie et al. 1998, Robinson and Bennett 2004) but very few on bats, an exception being Halstead (1977). Some of the data, such as carrying capacity, that are required to make assessments of sustainability using classical methods are difficult to obtain for bats. Nevertheless, Vardon and Tidemann (1995) suggested that a sustainable harvest of Australian Pteropus fruit bats could reduce the demand for declining and threatened Pteropus from the Pacific Islands.

In Madagascar sustainability could be achieved through cooperation with local communities, government and scientists. Initial assessments would necessitate field studies on population size and turnover as well as detailed recording of harvests. Management options include charging visiting hunters, implementing a closed season or prohibiting the use of firearms. Each of these will depend on the particular socioeconomic and cultural conditions in the area of the roost. Hunting bats at their feeding sites is probably less of a conservation threat if roosts are protected and offers a compromise between consuming and conserving bats.

There are a number of research and conservation priorities which, if addressed, could assist in the more robust assessment of the impact of hunting and the role of bats as bushmeat. They could also lead towards viable community-driven conservation management plans and a reduction in local extirpations.

ECOLOGICAL DATA There are few data on the

breeding biology and roosting ecology of bats in Madagascar. New information on roost location, dispersal patterns, productivity, and population size is therefore needed.

DISEASE TRANSFER A more thorough virological survey is

needed of the bat species that are most commonly consumed by people to assess possible human health risks from eating bats.

HARVESTING AND TRADE In conjunction with ecological information, data are needed on the dynamics of the bushmeat trade and harvesting patterns. In particular, seasonal and regional variation in the commercial aspects of bat bushmeat is required.

CULTURAL ISSUES Aside from the ecological and economic issues, it is important to determine the influence of culture and tradition. This should address taste preferences, taboos and non-food uses of bats.

ROOST CONSERVATION Roosts sites need pro-

tection from hunting, habitat loss (e.g. conversion to farm land) and other disturbances (e.g. people visiting caves). Important roosts in each of Madagascar's regions should be identified and conservation plans proposed.

SUPPORTING COMMUNITIES Local institutions need regular support to monitor and conserve bat roosts, especially in sites subject to heavy exploitation from outsiders. 
Sustainable bat conservation is possible in the long term in Madagascar, if major issues are addressed, such as the implementation of conservative harvests, providing communities with greater control over exploitation by visiting hunters, and creating a network of roosts that are protected from all forms of hunting.

\section{ACKNOWLEDGEMENTS}

This manuscript followed from a series of stimulating discussions with Marcus Rowcliffe and Julia Jones about bats and bushmeat in Madagascar. Some of the data reviewed here were presented at a UEA Madagascar Symposium in March 2007. This review would have been impossible without the contributions of our coworkers in Madagasikara Voakajy and its partner organizations: D. Andriafidison, R. A. Andrianaivoarivelo, A. Rabearivelo, V. H. Rahaingodrahety, C. Rahaingonirina, I. M. O. Raharinantenaina, S. Raharimbola, A. Rakotoarivelo, M. Ralisata, T. Ramihangihajason, R. Rampilamanana, F. H. Randrianandrianina, N. Razafindrakoto and H. J. Razafimanahaka. We also thank: C. Hawkins, A. F. Kofoky, E. Long, T. Mbohoahy, M. Raheriarisena, J. Ranivo and F. H. Ratrimomanarivo. We would also like to thank the following people for supporting our conservation work: C. Andrianarivo, R. Brett, B. Donaldson, A. F. A. Hawkins, J. L. Mackinnon, J.-P. Paddack, D. Rakotondravony, J.-B. Ramanamanjato, O. R. Ramilijaona, V. Raminoarisoa, N. Raminosoa, N. Ratsifandrihamanana, J. Ratsirarson, J. Ratsimbazafy, H. Ravelomanantsoa, E. Razafimahatratra, F. Rejo-Fienena, M. Vincelette and A. Walsh. We are very grateful to the Malagasy government for giving us permission to undertake our work, which was done in collaboration with the Association Nationale pour la Gestion des Aires Protégées, the Département de Biologie Animale, Université d'Antananarivo, the Département de Biologie, Université de Toliara and the Département des Eaux et Forêts, Ecole Supérieure des Sciences Agronomiques, Université d'Antananarivo. Félicien Randrianandrianina prepared Figure 1. RKBJ was funded by the Darwin Initiative and we would also like to thank, BP Conservation Leadership Programme, Bat Conservation International, British Ecological Society, Cleveland Metroparks Zoo, Conservation International, Disney Wildlife Conservation Fund, Fauna and Flora International, Lubee Bat Conservancy, National Geographic Society, Peoples' Trust for Endangered Species, Rufford Small Grants, WWF Prince Bernhard Scholarship and the Wildlife Conservation Society for supporting our various bat conservation projects. An anonymous referee provided helpful comments on the first submission.

\section{REFERENCES}

Andriafidison, D., Andrianaivoarivelo, R.-A., Jenkins, R. K. B., Ramilijaona, O. R., Razanahoera, M., Mackinnon, J. and Racey, P. A. 2006. Nectarivory by endemic Malagasy fruit bats in the dry season. Biotropica 38: 85-90.

Andrianaivoarivelo, R. A., Ramilijaona, O. R. and Andriafidison, D. 2007. Rousettus madagascariensis Grandidier 1929 feeding on Dimnocarpus longan in Madagascar. African Bat Conservation News 11: 3-4.

Andrianaivoarivelo, R. A., Ranaivoson, N., Racey, P. A. and Jenkins, R. K. B. 2006. The diet of three synanthropic bats (Chiroptera: Molossidae) from eastern Madagascar. Acta Chiropterologica 8: 439-444.

Bakarr, I. M., de Fonseca, G. A. B., Mittermeier, R., Rylands, A. B. and Painemilla, K. W. 2001. Hunting and bushmeat utilization in the African rainforest. Advances in Applied Biodiversity Science. Number 2. Centre for Applied Biodiversity Science, Conservation International, Washington, DC.
Bates, P. J. J., Ratrimomanarivo, F. H., Harrison, D. and Goodman, S. M. 2006. A review of pipistrelles and serotines (Chiroptera: Vespertilionidae) from Madagascar, including the description of a new species of Pipistrellus. Acta Chiropterologica 8: 299-234.

Bollen, A. and van Elsacker, L. 2002. Feeding ecology of Pteropus rufus (Pteropodidae) in the littoral forest of Sainte Luce, SE Madagascar. Acta Chiropterologica 4: 33-47.

Bowen-Jones, E., Abrutat, D., Markham, B. and Bowe, S. 1997. Flying foxes on Choiseul (Solomon Islands) - the need for conservation action. Oryx 31: 209-217

Breed, A. C., Field, H. E., Epstein, J. H. and Daszak, P. 2006. Emerging Henipavirus and flying foxes - conservation and management perspectives. Biological Conservation 131: 211-220.

Brooke, A. P. and Tschapka, M. 2002. Threats from overhunting to the flying fox Pteropus tonganus (Chiroptera: Pteropodidae) on Niue Island, South Pacific Ocean. Biological Conservation 103: 343-348.

Cardiff, S. G. 2006. Bat cave selection and conservation in Ankarana, northern Madagascar. Master's thesis. Columbia University, New York.

Corlett, R. T. 2007. The impact of hunting on the mammalian fauna of tropical Asian forests. Biotropica 39: 292-303.

Craig, P., Trail, P. and Morrell, T. E. 1994. The decline of fruit bats in American Samoa due to hurricanes and overhunting. Biological Conservation 69: 261-266.

de Merode, E., Homewood, K. and Cowlishaw, G. 2004. The value of bushmeat and other wild foods to rural households living in extreme poverty in the Democratic Republic of Congo. Biological Conservation 118: 573-581.

Durbin, J. 2007. New legislation for the protection of Malagasy species. Lemur News 11: 4-6.

Fa, J. E., Peres, C. A. and Meeuwig, J. 2002. Bushmeat exploitation in tropical forests: an intercontinental comparison. Conservation Biology 16: $232-237$

Fa, J. E., Ryan, S. F. and Bell, D. J. 2005. Hunting vulnerability, ecological characteristics and harvest rates of bushmeat species in Afrotropical forests. Biological Conservation 121: 167-176.

Fa, J. E., Seymour, S., Dupain, J., Amin, R., Albrechsten, L. and MacDonald, D. 2006. Getting to grips with the magnitude of exploitation: bushmeat in the Cross-Sanaga Rivers region, Nigeria and Cameroon. Biological Conservation 129: 497-510.

Fitzgibbon, C. D., Mogaka, H. and Fanshawe, J. H. 1995. Subsistence hunting in Arabuko-Sokoke forest, Kenya, and its effects on mammal populations. Conservation Biology 9: 1116-1126.

Funmilayo, O. 1976. Diet and roosting damage and environmental pollution by the straw-colored fruit bat in south-western Nigeria. The Nigerian Field 41: 136-142.

Funmilayo, O. 1978. Fruit bats for meat: are too many taken? Oryx 14: $377-$ 78.

Garcia, G. and Goodman, S. M. 2003. Hunting of protected animals in the Parc National d'Ankarafantsika, north-western Madagascar. Oryx 37: 115-118.

Golden, C. D. 2005. Eaten to endangerment: mammal hunting and the bushmeat trade in Madagascar's Makira Forest. Unpublished thesis Harvard College. $131 \mathrm{pp}$

Goodman, S. M. 2006. Hunting of Microchiroptera in south-western Madagascar. Oryx 40: 225-228.

Goodman, S. M., Andriafidison, D., Andrianaivoarivelo, R. A., Cardiff, S. G., Ifticene, E., Jenkins, R. K. B., Kofoky, A., Mbohoahy, T., Rakotondravony, D., Ranivo, J., Ratrimomanarivo, F. H., Razafimanahaka, H. J., Razakarivony, V. and Racey, P. A. 2005. The distribution and conservation of bats in the dry regions of Madagascar. Animal Conservation 8: $153-165$.

Goodman, S. M., Raherilalao, M. J., Rakotomalala, D., Rakotondravony, D., Raselimanana, A. P., Razakarivony, V. R. and Soarimalala, V. 2002. Inventaire des vertébrés du Parc National de Tsimanampetsotsa (Toliara). Akon'ny Ala 28: 1-36.

Goodman, S. M. and Ranivo, J. 2004. The taxonomic status of Neoromicia somalicus malagasyensis. Mammal Biology 69: 434-438. 
Goodman, S. M. and Raselimanana, A. P. 2003. Hunting of wild animals by Sakalava of the Menabe region: a field report from Kirindy-Mite. Lemur News 8: 4-6.

Goodman, S. M., Soarimalala, V. and Ganzhorn, J. U. 2004. La chasse aux animaux sauvages dans la forêt de Mikea. In: Inventaire floristique et faunistique de la forêt de Mikea: paysage écologique et diversité biologique d'une préoccupation majeure pour la conservation, A. P. Raselimanana, and S. M. Goodman (eds.), pp 95-100. Recherches pour le Développement. Série Sciences Bioloqiques. Centre d'Information et de Documentation Scientifique et Technique No. 21, Antananarivo.

Halstead, L. B. 1977. Fruit bats - an example of wildlife management. The Nigerian Field 42: 50-56.

Heaney, L. R. and Heideman, P. D. 1987. Population biology and estimates of abundance of fruit bats (Pteropodidae) in Philippine submontane rainforest. Journal of Zoology 218: 565-586.

Iehlé, C., Razafitrimo, G., Razainirina, J., Andriaholinirina, N., Goodman, S. M., Faure, C., Georges-Courbot, M.-C., Rousset, D. and Reynes, J.-M. 2006. Henipavirus and Tioman Virus antibodies in pteropodid bats, Madagascar. Emerging Infectious Diseases 13: 159-161.

IUCN, 2007. 2007 IUCN Red List of Threatened Species. <www.iucnredlist. org > accessed on 15 November 2007.

Jenkins, R. K. B., Andriafidison, D., Razafimanahaka, H. J., Rabearivelo, A., Razafindrakoto, N., Andrianandrasana, R. H., Razafimahatratra, E. and Racey, P. A. 2007a. Not rare, but threatened: the endemic Madagascar Flying Fox Pteropus rufus in a fragmented landscape. Oryx 41: 263-271.

Jenkins, R. K. B., Kofoky, A. F., Russ, J. M., Andriafidison, D., Siemers, B. M., Randrianadrianina, F., Mbohoahy, T., Rahaingondrahety, V. N. and Racey, P. A. 2007b. Ecology and conservation of bats in the southern Anosy Region. In: Biodiversity, Ecology and Conservation of Littoral Forest Ecosystems in Southeastern Madagascar, Tolagnaro (Fort Dauphin), J. U. Ganzhorn, S. M. Goodman and M. Vincelette (eds.) , pp 209-222. SI/MAB Series No. 11. Smithsonian Institution, Washington, D.C.

Kofoky, A. F., Andriafidison, D., Ratrimomanarivo, F. H., Razafimanahaka, J. H., Rakotondravony, D., Racey, P. A. and Jenkins, R. K. B. 2007. Habitat use, roost selection and conservation of bats in Tsingy de Bemaraha National Park, Madagascar. Biodiversity and Conservation 16: 1039-1053.

Linton, R. 1933. The Tanala. A Hill Tribe of Madagascar. The Field Museum of Natural History Anthropological Series. Volume XXII, 1-327.

Lee, R. J., Gorog, A. J., Dwiyahreni, A., Siwu, S., Riley, J., Alexander, H., Paoli, G. D. and Ramono, W. 2005. Wildlife and trade implications for law enforcement in Indonesia: a case study from North Sulawesi. Biological Conservation 123: 477-488.

Mackinnon, J. L., Hawkins, C. E. and Racey, P. A. 2003. Pteropodidae, Fruit Bats, Fanihy, Angavo. In: The Natural History of Madagascar, S. M. Goodman and J. P. Benstead (eds.), pp. 1299-1302. The University of Chicago Press, Chicago.

Messenger, S. L., Rupprecht, C. E. and Smith, J. E. 2003. Bats, Emerging Virus Infections, and the Rabies Paradigm. In: Bat Ecology, T. H. Kunz and M. B. Fenton (eds.), pp. 622-679. The University of Chicago Press, Chicago.

Mickleburgh, S. P., Hutson, A. M. and Racey, P. A. 1992. Old World Fruit Bats: an Action Plan for their Conservation. IUCN, Gland. Switzerland.

Monson, S. C., Bannack, S. A. and Cox, P. A. 2003. Conservation implications of Chamorro consumption of flying foxes as a possible cause of amyotrophic lateral sclerosis - Parkinson Dementia Complex in Guam. Conservation Biology 17: 678-686.

O'Brien, S., Emahalala, E. R., Beard, V., Rakotondrainy, R. M., Reid, A., Raharisoa, V. and Coulson, T. 2003. Decline of the Madagascar radiated tortoise Geochelone radiata due to overexploitation. Oryx 37: 338-343.

Picot, M. M. 2005. Etude de l'écologie du Megachiroptère Eidolon dupreanum (Pollen, 1866) et son rôle dans la dispersion des graines en lisière du corridor forestier reliant les Parcs Nationaux de Ranomafana et d'Andringitra. Unpublished. Département de Biologie Animale, Faculté des Sciences. Université d'Antananarivo, Antananarivo. 77 pp.

Picot, M. M., Jenkins, R. K. B., Ramilijaona, O. R., Racey, P. A. and Carrière, S. M. 2007. The feeding ecology of Eidolon dupreanum (Chiroptera: Pteropodidae) in eastern Madagascar. African Journal of Ecology 45 645-650.
Racey, P. A., Goodman, S. M. and Jenkins, R. K. B. (in press). The ecology and conservation of Malagasy bats. In: Island Bats, T. H. Fleming and P. A. Racey (eds.). The University of Chicago Press. Chicago.

Rahaingodrahety, V. H. 2007. Ecologie et conservation de Pteropus rufus dans la Région de I'Anosy (cas des Communes Rurales d'Amboasary Sud et de Mahatalaky). Unpublished. Mémoire Ingénieur. Ecole Supérieure des Sciences Agronomiques, Département des Eaux et Forêt, Université d'Antananarivo.

Rakotoarivelo, A. R. and Randrianandrianina, F. H. 2007. A chiropteran survey of the Lac Kinkony-Mahavavy area in western Madagascar. African Bat Conservation News 12: 2-5.

Rakotonandrasana, E. N. and Goodman, S. M. 2007. Bat inventories of the Madagascar offshore islands of Nosy Be, Nosy Komba and Ile SainteMarie. African Bat Conservation News 12: 6-10.

Rakotondravony, H. 2006. Communautés locales et gibiers dans la région de Daraina, extrême Nord-Est de Madagascar. Madagascar Conservation \& Development 1: 19-21.

Randriamanalina, M. H., Rafararano, L., Babary, L. and Laha, R. 2000. Rapport des enquêtes sur les chasses dans les Fokontany d'Ivondro, d'Erara et d’Etsilesy. Lemur News 5: 11-14.

Ranivo, J. 2001. Contribution à l'étude de la biologie et de l'effet de la prédation humaine sur la roussette: Eidolon dupreanum (Pollen, 1866). Unpublished Mémoire de D.E.A. Département de Biologie Animale, Faculté des Sciences, Université d'Antananarivo.

Robinson, J. G. and Bennett, E. L. 2004. Having your wildlife and eating it too: an analysis of hunting sustainability across tropical ecosystems. Animal Conservation 7: 397-408

Struebig, M. J., Harrison, M. E., Cheyne, S. M. and Limin, S. H. 2007. Intensive hunting of large flying foxes Pteropus vampyrus natunae in Central Kalimantan, Indonesian Borneo. Oryx 41: 390-393.

Vardon, M. J. and Tidemann, C. R. 1995. Harvesting of flying-foxes (Pteropus spp.) in Australia: could it promote the conservation of endangered Pacific island species? In: Conservation through Sustainable use of Wildlife. G. C. Grigg, P. T. Hale and D. Lunney (eds.). pp 82-85. Centre for Conservation Biology, The University of Queensland.

Wiles, G. J., Enbring, J. and Otobed, D. 1997. Abundance, biology and human exploitation of bats in the Palau Islands. Journal of Zoology 241: 203227.

Willcox, A. S. and Nambu, D. M. 2007. Wildlife hunting practices and bushmeat dynamics of the Banyangi and Mbo people of southwestern Cameroon. Biological Conservation 134: 251-261.

Wilkie, D. S., Curran, B., Tshombe, R. and Morelli, G. A. 1998. Modeling the sustainability of subsistence farming and hunting in the Ituri Forest of Zaire. Conservation Biology 12: 137-147. 